\title{
A systematic review of the effectiveness of non- health facility based care delivery of antiretroviral therapy for people living with HIV in sub-Saharan Africa measured by viral suppression, mortality and retention on ART
}

Mohammed Limbada ${ }^{1 *}\left(\mathbb{D}\right.$, Geiske Zijlstra ${ }^{2+}$, David Macleod ${ }^{3}$, Helen Ayles $^{1,3}$ and Sarah Fidler ${ }^{4}$

\begin{abstract}
Background: Alternative models for sustainable antiretroviral treatment (ART) delivery are necessary to meet the increasing demand to maintain population-wide ART for all people living with HIV (PLHIV) in sub-Saharan Africa. We undertook a review of published literature comparing health facility-based care (HFBC) with non-health facility based care (nHFBC) models of ART delivery in terms of health outcomes; viral suppression, loss to follow-up, retention and mortality.

Methods: We conducted a systematic search of Medline, Embase and Global Health databases from 2010 onwards. UNAIDS reports, WHO guidelines and abstracts from conferences were reviewed. All studies measuring at least one of the following outcomes, viral load suppression, loss-to-follow-up (LTFU) and mortality were included. Data were extracted, and a descriptive analysis was performed. Risk of bias assessment was done for all studies. Pooled estimates of the risk difference (for viral suppression) and hazard ratio (for mortality) were made using randomeffects meta-analysis.

Results: Of 3082 non-duplicate records, 193 were eligible for full text screening of which 21 published papers met the criteria for inclusion. The pooled risk difference of viral load suppression amongst 4 RCTs showed no evidence of a difference in viral suppression (VS) between nHFBC and HFBC with an overall estimated risk difference of 1\% [95\% Cl -1,4\%]. The pooled hazard ratio of mortality amongst 2 RCTs and 4 observational cohort studies showed no evidence of a difference in mortality between nHFBC and HFBC with an overall estimated hazard ratio of 1.01 $[95 \% \mathrm{Cl} 0.88,1.16]$. Fifteen studies contained data on LTFU and 13 studies on retention. Although no formal quantitative analysis was performed on these outcomes due to the very different definitions between papers, it was observed that the outcomes appeared similar between HFBC and nHFBC.
\end{abstract}

\footnotetext{
* Correspondence: mohammed@zambart.org.zm

${ }^{+}$Mohammed Limbada and Geiske Zijlstra contributed equally to this work. 'Zambart House, PO Box 50697, UNZA-Ridgeway Campus, Lusaka, Zambia Full list of author information is available at the end of the article
}

(c) The Author(s). 2021 Open Access This article is licensed under a Creative Commons Attribution 4.0 International License, which permits use, sharing, adaptation, distribution and reproduction in any medium or format, as long as you give appropriate credit to the original author(s) and the source, provide a link to the Creative Commons licence, and indicate if changes were made. The images or other third party material in this article are included in the article's Creative Commons licence, unless indicated otherwise in a credit line to the material. If material is not included in the article's Creative Commons licence and your intended use is not permitted by statutory regulation or exceeds the permitted use, you will need to obtain permission directly from the copyright holder. To view a copy of this licence, visit http://creativecommons.org/licenses/by/4.0/ The Creative Commons Public Domain Dedication waiver (http://creativecommons.org/publicdomain/zero/1.0/) applies to the data made available in this article, unless otherwise stated in a credit line to the data. 
Conclusions: Review of current literature demonstrates comparable outcomes for nHFBC compared to HFBC ART delivery programmes in terms of viral suppression, retention and mortality.

PROSPERO number: CRD42018088194.

Keywords: Human immunodeficiency virus, Antiretroviral therapy, Sub-Saharan Africa, Community-based delivery

\section{Background}

There are an estimated 37.9 million people living with human immunodeficiency virus (HIV) globally and 32 million people have died from AIDS-related illnesses since the start of the epidemic [1]. The HIV epidemic has disproportionately affected Africa, particularly sub-Saharan Africa (SSA) which has the largest burden of the disease. Although the region accounts for approximately $6.2 \%$ of the world's total population, it is home to over $50 \%$ (20.6 million) of the total number of PLHIV globally, with over 800,000 new infections recorded in 2018 [2].

Antiretroviral therapy (ART) controls viral replication to below the limit of detection and in doing so, improves survival $[3,4]$ and limits the risk of onward viral transmission [5, 6], but requires daily lifelong adherence to oral medication. Stopping ART invariably leads to rapid viral recrudescence and reversal of its beneficial effects [7]. In order to significantly reduce the number of new HIV infections globally, UNAIDS in 2014 set coverage targets by 2020 for the three key indicators; knowledge of HIV status for $90 \%$ of people living with HIV (PLHIV), ART access for at least $90 \%$ of all PLHIV and viral suppression for at least $90 \%$ of all of those living with HIV on ART; the "90-90-90 targets" with the aspiration to end the HIV epidemic by 2030 [8]. Following the World Health Organization (WHO) 2015 recommendation of lifelong ART for all PLHIV regardless of CD4 count and clinical staging [9], there has been substantial progress in scaling up ART programs; and by mid-2018, $84 \%$ of low- and middleincome countries had adopted these guidelines [10, 11] to provide universal treatment to all PLHIV. Despite the high HIV burden, SSA has made tremendous progress in treatment coverage and by 2018, 85\% of PLHIV were aware of their status and $67 \%$ (13.8 million) were on treatment $[12,13]$.

Maintaining this unprecedented scale-up of ART services poses a challenge in high HIV burden resource limited settings, especially in SSA where healthcare facilities are overburdened with long waiting times, inadequate and overburdened human resources, transportation costs, congestion and long waiting times at the health facility-based care $(\mathrm{HFBC})[14,15]$, leading to poor retention in care and adherence. Recent data from sub-Saharan Africa (SSA) shows 5- year retention on ART is close to 60\% [16-21].

Decentralizing ART provision services outside of the HFBC into the communities holds the promise of improving the continuum of care and facilitating access to treatment. Various models of non-health facility-based care (nHFBC) [22] have been piloted and implemented in high burden low resource settings and are now being increasingly recognised as safe and effective alternatives to the current standard model of health facility-based care in SSA [23, 24]. These include; healthcare workermanaged groups (adherence clubs); client managed group models (community adherence groups (CAGs)); and out-of-facility individual models (community-based distribution points (CBDPs) and home-based delivery). Adherence clubs consists of a group of 15-30 stable PLHIV who meet up at a venue within or outside the HFBC space, once every 2-3 months where they receive their adherence support and pre-packed medications by a trained lay worker or healthcare worker. Club members are seen once or twice-yearly at the clinic for routine clinical review and laboratory tests [25-29]. CAGs, originally developed by Médecins Sans Frontiéres (MSF) in Tete, Mozambique, also target stable patients who receive ART refills and adherence support in a group, where each member of the group takes turns collecting ART for all group members. Each group is composed of approximately six patients who meet up every 2-3 months, and each member has their routine clinical visit once or twice-yearly [26, 30-32]. Out-of-facility models vary according to the services delivered, by whom and where in the community these services are provided. In home-based delivery, clients receive their adherence support and pre-packed medications once every $3 \mathrm{~m}$ in their homes by a trained lay worker [33, 34]. CBDPs allow patients to pick up their drug refills at a designated place in the community $[26,27,35,36]$.

These models of care are best directed towards stable adult patients, defined as those with suppressed HIV viral loads on ART for more than $6 \mathrm{~m}$. It allows them to receive treatment and sometimes medical care within their communities with ongoing adherence support where needed, and may sometimes involve community health workers (CHWs) dispensing pre-packedART, thus reducing the frequency of clinic visits. 
Ideal nHFBC models of ART delivery must be sustainable and safe. They must confer similar successful clinical outcomes in order to effectively contribute to the decrease of HIV transmission and extension of life expectancy. Feasibility of these models need to be stringently evaluated and compared with concurrent HFBC in order to determine the safe sustainable delivery of ART to UNAIDS targets. Several systematic reviews published recently have shown that community programs increase both affordability and accessibility to ART [24] and have shown that there are no significant differences in optimal ART adherence, virological suppression (VS), all-cause mortality and loss-to follow-up (LTFU) between patients assigned to nHFBC and HFBC $[23,37]$. This review looks at programmatic data and trials from 2010 onwards in order to provide an update on large amounts of recently published data, as several models have been rolled out providing more data on clinical outcomes.

We undertook a review of published literature comparing HFBC with nHFBC models of ART delivery in terms of health outcomes; viral suppression, loss to follow-up, retention and mortality among PLHIV. We included all descriptions of novel programmatic delivery of ART in nHFBC settings, and compared where available specific outcomes between HFBC and nHFBC, including VS, mortality, retention and LTFU.

\section{Methods}

\section{Search strategy}

A systematic electronic search of peer-reviewed literature was conducted most recently on the 21 August 2019 in the following databases: Medline, Embase and Global Health. The search strategy was created with the support of a medical librarian; key terms were identified to combine ART AND nHFBC AND SSA. The search strategy is outlined in full in Additional file 1: Appendix 1. The review was prospectively registered with online database PROSPERO (ID=CRD42018088194). In addition to the databases, two key UNAIDS reports and all WHO guidelines, and their references, from 2010 onwards were reviewed.

\section{Eligibility criteria}

Articles were considered for inclusion if they described the effectiveness of one of four nHFBC methods of delivery of ART in sub-Saharan African settings: adherence clubs, CAGs, CBDPs and home-based delivery. Adherence clubs were included irrespective of whether they were physically located within the healthcare facility or in the community as they are run independently and are considered novel care pathways outside the routine HFBC pathway. Appointment spacing, and fast track refills that take place within the facility were excluded as this was considered to be part of standard HFBC pathway. Studies had to measure a clinical outcome, either; retention in care, LTFU in accordance with WHO and national guidelines definitions, transfer to alternative care, viral load (VL), viral suppression (VS), CD4 count or mortality. The definition of LTFU varied by study and year, but papers were considered eligible if they defined LTFU in accordance with standard WHO and guideline practices [38]. While some studies reported patient outcomes within the LTFU cohort, such as death or transfer to other services, this was not essential for inclusion. The definitions of viral suppression were varied between studies as laboratory assays changed, but for this analysis we included all papers that reported to $<1000$ copies HIV RNA/mL.

For inclusion, studies were not required to have a comparator current standard of care control group. It was not necessary for studies to be delivering ART in isolation of other interventions, such as counselling. There was no restriction on study population age, history of infection or line of ART.

Original research articles were included, and systematic reviews were excluded. Where data from the same cohort was published multiple times, the most recently available publication was included. The search was conducted in English only due to available expertise, time and budgetary restrictions. A publication date limit of 1st January 2010 until 31st August 2019 was applied to the searches in all databases as the aim was to review the current published literature and update previously published review articles [24].

\section{Data extraction and quality appraisal}

All database search results were imported into EndNote software (EndNote X8.2) for duplicate removal, and then into Covidence systematic review software, which was used for screening [39]. The screening of titles and abstracts and the full text reviews of eligible articles were done in duplicate by two independent reviewers (GZ, $\mathrm{ML}$ ). All conflicts were resolved through discussion between both reviewers, and a third reviewer (SF). Where full texts of abstracts were not available, these were accessed via the British Library. Additional articles were identified by examining references of articles included for full text review (Fig. 1). Articles considered eligible for inclusion were read in full by GZ \& ML, and approved by reviewer SF.

Data was extracted in duplicate by two reviewers (GZ, $\mathrm{ML}$ ), including: first author, year of publication, country of origin, study design, sample size, the community model used to deliver ART, outcomes, length of follow up and who was responsible for ART provision. All discrepancies in data extracted were solved through discussion between both reviewers. Results of this data 


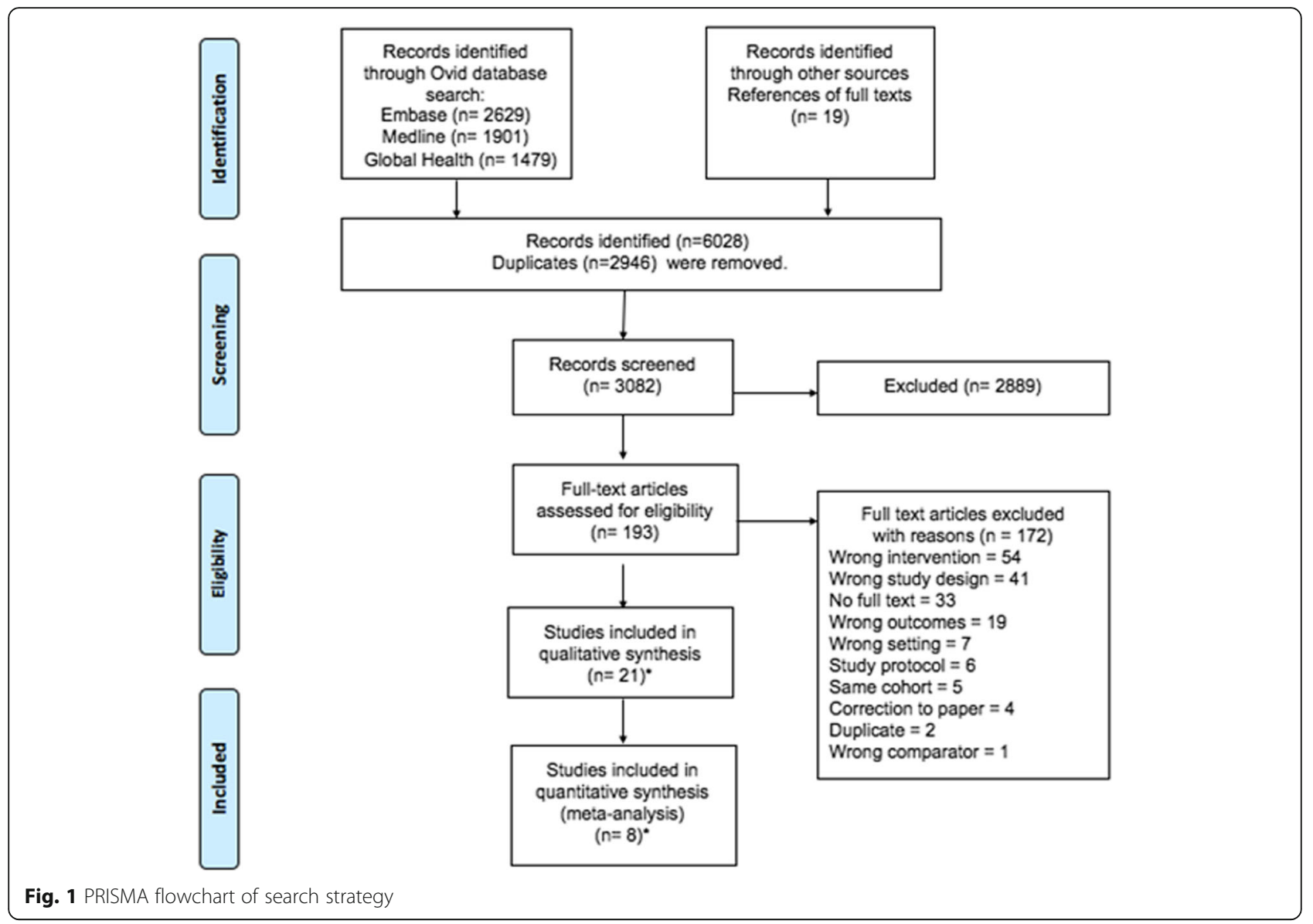

extraction were summarized in Table 1. Quality analysis was done by reviewers GZ and ML using the Cochrane tool for risk of bias for all randomised control trials (RCTs) and using the Newcastle-Ottawa scale [58, 59] for cohort studies, which can be found summarised in Appendices 2 and 3.

\section{Quantitative and qualitative analysis}

Results were extracted for VS (thresholds defined in the articles ranged from $\leq 1000-400$ copies HIV RNA/mL), mortality and LTFU/retention in care. Studies with variable definitions of VS were still considered eligible for quantitative comparison. Pooled estimates of the comparison between nHFBC and HFBC were calculated for both VS and mortality using random-effects metaanalysis. When comparing VS, the pooled risk difference was the reported statistic, and for mortality the pooled hazard ratio was reported. Due to the large variations in the definitions of LTFU and retention in care between papers, only a descriptive analysis was carried out in accordance with the Synthesis without meta-analysis (SWiM) in systematic reviews: reporting guideline [60]. For quality assessment, RCTs were risk assessed using the Cochrane Risk of Bias tool [59] which can be found in full in Additional file 2: Appendix 2. Quality assessment of cohort studies was done using the NewcastleOttawa Scale (Additional file 3: Appendix 3) [58].

\section{Results}

Our search identified 3082 non-duplicate records, of which 2889 were excluded after abstract and title screening against our search criteria. One hundred ninetythree records were eligible for full text screening, of which 21 published papers were eligible for inclusion in our analysis (Fig. 1).

Of the 21 articles included, results were presented from a total of six randomized control trials (RCTs) [37, 40-44], 15 observational cohort studies [32, 36, 37, 4556] and one cross-sectional study [57] (one article presented the results from both an RCT and a cohort study). These studies were conducted in SSA, including: South Africa, Uganda, Tanzania, Mozambique, Kenya, Zimbabwe, Eswatini and Democratic republic of Congo. The number of participants included in the studies ranged from 129 to 129,936 , and the design and methodology of the included studies are detailed in Table 1. Our included articles represented nHFBC models that provided service delivery either as individual or group 
Table 1 Characteristics of the studies and their Design, nHFBC model and key findings

\begin{tabular}{|c|c|c|c|c|c|c|}
\hline Study & Setting & $\begin{array}{l}\text { Non-facility based } \\
\text { model }\end{array}$ & Comparator & $\begin{array}{l}\text { Sample } \\
\text { Size }\end{array}$ & $\begin{array}{l}\text { Length of } \\
\text { follow-up }\end{array}$ & Outcomes and key findings \\
\hline \multicolumn{7}{|c|}{ RANDOMIZED CONTROL TRIALS } \\
\hline Fox 2019 [37] & South Africa & Adherence clubs & $\begin{array}{l}\text { Health care } \\
\text { facility }\end{array}$ & $\begin{array}{l}N=596 \\
\text { AC } n= \\
275 \\
\text { HCF } n= \\
294\end{array}$ & 18 months & $\begin{array}{l}\text { Viral Suppression - comparable } 12 \text { months viral suppression } \\
\text { between the intervention (80\%) and control (79.6\%) arms (aRD: } \\
\text { 3.8\%; } 95 \% \mathrm{Cl} \text { : }-6.9 \text { to } 14.4 \%) \text {. } \\
\text { Retention - AC's had a higher 1-year retention ( } 89.5 \% \text { vs } \\
81.6 \% \text {, aRD:8.3\%; } 95 \% \text { Cl: } 1.1 \text { to } 15.6 \%)\end{array}$ \\
\hline $\begin{array}{l}\text { Hanrahan } 2019 \\
{[40]}\end{array}$ & South Africa & $\begin{array}{l}\text { Community Adherence } \\
\text { clubs }\end{array}$ & $\begin{array}{l}\text { Health care } \\
\text { facility clubs } \\
\text { (Standard of } \\
\text { care) }\end{array}$ & $N=775$ & 24 months & 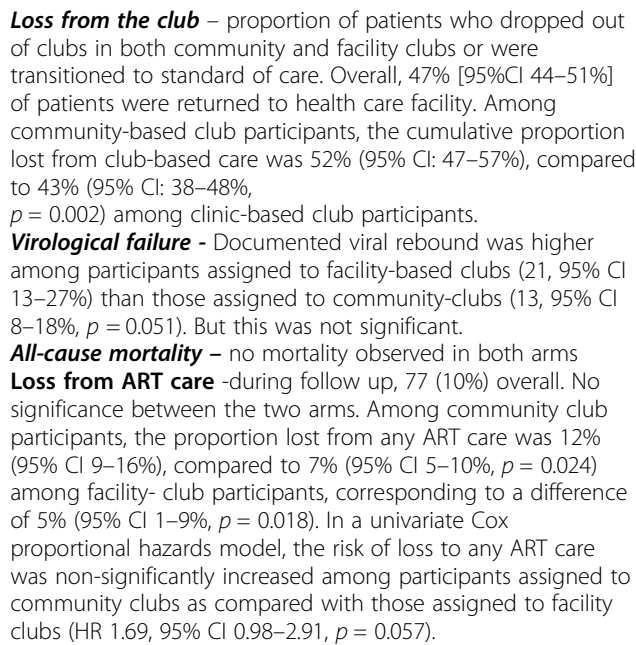 \\
\hline
\end{tabular}

$\begin{array}{llll}\text { Geldsetzer } 2018 \text { Tanzania Home ART delivery } & \text { Health care } \\ \text { [41] facility } & N=2172 \quad 326 \text { days } \\ & & H D n= \\ & 1163 \\ & \text { HCF } n= \\ & 1009\end{array}$

$\begin{array}{lll}\text { Woodd } 2014 \quad \text { Uganda Home ART delivery } & \text { Health care } & N=1453 \quad 28 \text { months } \\ \text { [42] facility } & H D n= \\ & 859 \\ & & H C F n= \\ & 594\end{array}$
Health care
facility

Health care facility
$\mathrm{HD} n=42$ months

594 HCF $n=$ 859

$\mathrm{HD} n=$ 96 $\mathrm{HCF} n=$ 112

Virological failure - $10.9 \%$ (95/872) in the control arm and 9.7\% (91/943) in the intervention arm were failing at the end of the study period.

Risk ratio demonstrated non-inferiority of the HBC to HCF (RR 0.89 [1-sided 95\% Cl 0.00-1.18])

Lost to follow-up - $18.9 \%$ in HBD versus $13.6 \%$ in HCF. No $P$ value or $\mathrm{Cl}$ reported.

Mortality $-0.09 \%$ in $\mathrm{HBD}$ versus $0.2 \%$ in $\mathrm{HCF}$. No $\mathrm{P}$ value or $\mathrm{Cl}$ reported.

Home delivery of ART and support leads to similar survival rates as clinic-based care.

Mortality - One hundred and ninety-seven participants died over a median follow-up time of 28 months (IQR 15-35) giving an overall mortality rate of 6.36 deaths per 100 person-years [95\% confidence interval (Cl) 5.53-7.32].

$110(25 \%)$ deaths in participants with baseline CD4 $<50$ cells and 87 (9\%) in those with higher baseline CD4.Among participants with baseline $\mathrm{CD4}^{+}$count $<50$ cells/ $\mu$ l, mortality rates were similar for the home and facility-based arms; adjusted mortality rate ratio 0.80 [95\% confidence interval $(\mathrm{Cl})$ $0.53-1.18$ ] compared with 1.22 (95\% Cl 0.78-1.89) for those who presented with higher $\mathrm{CD}^{+}$cell count.

In CD4 counts $<50$ cells - crude mortality RR 0.81 and In CD4 counts higher - crude mortality RR 0.55

Lost to follow up $-1.8 \%$ among those with CD $4<50$ and $2.6 \%$ among those with CD4 at least 50 .

Mortality - in the facility there were 117 deaths (mortality rate 6.3 per 100 persons per yrs.) whereas in $\mathrm{HBD}, 80$ deaths (mortality rate 6.5 per 100 person yrs.). The one, two and three year survival probabilities $(95 \% \mathrm{Cl})$ were 0.89 (0.87-0.91), 0.86 $(0.84-0.88)$ and $0.85(0.83-0.87)$ respectively

28 months Home delivery of ART and support resulted in similar clinical outcomes as clinic care but with half the number of clinic visits. Task-shifting and mobile technologies can deliver safe and effective community-based care to PLHIV.

LTFU $-4.5 \%$ in the HCF and $5.2 \%$ in Home delivery $[95 \% \mathrm{Cl}$ : 0.24 to $3.03 ; p=1.0]$

Mortality - 0 in both arms

Viral rebound - no significant difference between the two groups (10.5\% in HBD and $13.5 \%$ in HCF, $95 \% \mathrm{Cl}$ : 0.54 to 3.31 , $p=0.65)$ 
Table 1 Characteristics of the studies and their Design, nHFBC model and key findings (Continued)

\begin{tabular}{|c|c|c|c|c|c|c|}
\hline Study & Setting & $\begin{array}{l}\text { Non-facility based } \\
\text { model }\end{array}$ & Comparator & $\begin{array}{l}\text { Sample } \\
\text { Size }\end{array}$ & $\begin{array}{l}\text { Length of } \\
\text { follow-up }\end{array}$ & Outcomes and key findings \\
\hline \multicolumn{7}{|c|}{ OBSERVATIONAL COHORT STUDIES } \\
\hline Fox 2019 [37] & South Africa & $\begin{array}{l}\text { Decentralized } \\
\text { medication delivery } \\
\text { (DMD) }\end{array}$ & $\begin{array}{l}\text { Health care } \\
\text { facility }\end{array}$ & $\begin{array}{l}N=578 \\
\text { DMD } n= \\
232 \\
\text { HCF } n= \\
346\end{array}$ & 18 months & \\
\hline Tun 2019 [45] & Tanzania & $\begin{array}{l}\text { Community Based ART } \\
\text { distribution (CBPDs) }\end{array}$ & $\begin{array}{l}\text { Health care } \\
\text { facility }\end{array}$ & $\begin{array}{l}\text { CBPD } \\
n=309 \\
\text { HCF } n= \\
308\end{array}$ & 6 months & $\begin{array}{l}\text { Retention in the CBDP - } 82.8 \% \text { vs } 82.1 \% \text { in the HCF at } 6 \\
\text { months } \\
\text { LTFU - } 53 \text { in the intervention and } 55 \text { in the HCF arms }\end{array}$ \\
\hline $\begin{array}{l}\text { Pasipamire } \\
2018 \text { [46] }\end{array}$ & Swaziland & $\begin{array}{l}\text { 1. Community } \\
\text { Adherence groups } \\
\text { (CAGs) 2. Facility Based } \\
\text { clubs } \\
\text { 3. Treatment outreach }\end{array}$ & No comparator & $\begin{array}{l}N=918 \\
\text { CAGs } \\
n=531 \\
\text { FBC } n= \\
289 \\
\text { Outreach } \\
n=98\end{array}$ & 12 months & $\begin{array}{l}\text { Retention in the models - The overall care model retention } \\
\text { was } 90.9 \text { and } 82.2 \% \text { at } 6 \text { and } 12 \text { months. Retention in the care } \\
\text { models differed significantly by model type, being lowest in } \\
\text { CAGs at all time points }(p<0.001) \text {. Only } 70.4 \% \text { of patients wer } \\
\text { retained in CAGs at } 12 \text { months compared with } 86.3 \% \text { in } \\
\text { comprehensive outreach and } 90.4 \% \text { in clubs. Retention in care } \\
\text { model was significantly higher in eligible patients compared } \\
\text { with non-eligible patients ( } 85.0 \text { and } 76.4 \% \text { at } 12 \text { months, } p= \\
0.017 \text {. } \\
\text { Retention to ART - over } 90 \% \text { from all three models and no } \\
\text { difference noted ( } p=0.52) \text {.Patients in CAGs had a higher risk } \\
\text { disengaging from the care model (aHR } 3.15,95 \% \text { Cl: } 2.01-4.95 \text {, } \\
P<0.001 \text { ) compared with treatment clubs. } \\
\text { Note: disengagement defined as LTFU, Death, return to clinica } \\
\text { Care) }\end{array}$ \\
\hline Myer 2017 [47] & South Africa & $\begin{array}{l}\text { Adherence clubs [post- } \\
\text { partum women] }\end{array}$ & $\begin{array}{l}\text { Health care } \\
\text { facility }\end{array}$ & $\begin{array}{l}N=110 \\
A C n=77 \\
H C F n= \\
33\end{array}$ & $\begin{array}{l}6 \text { months } \\
\text { post- } \\
\text { partum } \\
\text { follow-up }\end{array}$ & $\begin{array}{l}\text { Viral suppression - overall no difference in viral suppression } \\
\text { between the two groups. } \\
86 \% \text { of women remained in the evaluation through } 6 \\
\text { months postpartum; in this group, there were no } \\
\text { differences in } \mathrm{VL}<1000 \text { copies } / \mathrm{mL} \text { at six months } \\
\text { postpartum between women choosing HCFs }(88 \%) \text { vs. } \\
\text { adherence clubs }(92 \% ; p=0.483 \text {. }\end{array}$ \\
\hline
\end{tabular}

$\begin{aligned} \text { Vogt } 2017[48] & \begin{array}{l}\text { Democratic } \\ \text { Republic of }\end{array}\end{aligned}$ Congo (DRC)

centers

unity based refill No comparator $N=2259$

Tsondai 2017 South Africa Adherence clubs [49]

Decroo 2017 Mozambique [50]

Community ART groups (CAGs)

Health care facility

CAGs

$n=901$ HCF $n=$ 1505

\begin{tabular}{|c|c|c|c|c|c|}
\hline Auld 2016 [51] & Mozambique & $\begin{array}{l}\text { Community support } \\
\text { ART groups (CASG) }\end{array}$ & $\begin{array}{l}\text { Health care } \\
\text { facility }\end{array}$ & $\begin{array}{l}N=306 \\
335 \\
\text { CASG } \\
n=6766 \\
\text { HCF } n= \\
299,569\end{array}$ & 4 years \\
\hline $\begin{array}{l}\text { Grimsrud } 2016 \\
\text { [52] }\end{array}$ & South Africa & Adherence clubs & $\begin{array}{l}\text { Health care } \\
\text { facility }\end{array}$ & $\begin{array}{l}N=8150 \\
\mathrm{AC} n= \\
2113 \\
\text { HCF } n=\end{array}$ & 12 months \\
\hline
\end{tabular}

Attrition increased steadily after decentralizing services such as drug pick up points

Low attrition throughout follow-up

LTFU - $9.0 \%$ at 24 months

Mortality - $0.3 \%$ at 24 months

overall attrition was $5.66 / 100$ person years (95\% Cl: 4.97 to 6.45 )

Stable patients on ART can safely be offered differentiated care as they overall had good outcomes. Adherence clubs scaled up at large scale had had high levels of retention and viral suppression.

Retention - Retention was 95.2\% (95\% Cl: 94.0-96.4) at 12 months and $89.3 \%(95 \% \mathrm{Cl}: 87.1-91.4)$ at 24 months after AC enrolment.

Viral suppression - Of the $88.1 \%$ who had a viral load assessment, $97.2 \%(95 \% \mathrm{Cl}, 96.5-97.8)$ were virally suppressed < 400 copies $/ \mathrm{ml}$

LTFU - 4.2\% (135). Cumulative incidence of LTFU was $2.6 \%$

$(95 \% \mathrm{Cl}, 2.1-3.2)$ at 12 months, rising to $6.9 \%(95 \% \mathrm{Cl}, 5.7$ to 8.1$)$ at 24 months after AC enrolment.

Mortality $-0.1 \%(95 \% \mathrm{Cl},-0.01$ to 0.2$)$ at 12 months and $0.2 \%$ $(95 \% \mathrm{Cl},-0.01$ to 0.4$)$

LTFU - overall 12\% [11.2\% in HCF and 0.8\% in CAGs]. CAG members had a greater than fivefold reduction in risk of dying or being LTFU (adjusted HR: 0.18, 95\% Cl 0.11 to 0.29 ). Retention - 12-month and 24-month retention in care from the time of eligibility were 89.5 and $82.3 \%$ respectively among patients in individual care and 99.1 and $97.5 \%$ among those in CAGs $(p<0.0001)$

Mortality - similar rates in both groups $[0.3 \%$ among CASG at 2 yrs. and $1.4 \%$ at 4 yrs.]

CASG patients were associated with a 35\% lower LTFU rates [AHR 0.65; 95\% Cl:0.46, 0.91] but similar mortality.

Viral suppression - high rates of VLS among those who had a $V L$ result, but no comparison made between the two cohorts. LTFU - clubs were associated with a decreases risk of LTFU compared to facility in all crude and adjusted models. Clubs 
Table 1 Characteristics of the studies and their Design, nHFBC model and key findings (Continued)

\begin{tabular}{|c|c|c|c|c|c|c|}
\hline Study & Setting & $\begin{array}{l}\text { Non-facility based } \\
\text { model }\end{array}$ & Comparator & $\begin{array}{l}\text { Sample } \\
\text { Size }\end{array}$ & $\begin{array}{l}\text { Length of } \\
\text { follow-up }\end{array}$ & Outcomes and key findings \\
\hline & & & & 6037 & & $\begin{array}{l}\text { were associated with a } 67 \% \text { reduction in LTFU compared with } \\
\text { facility (aHR 0.33, [95\% Cl, 0.27-0.40]). }\end{array}$ \\
\hline $\begin{array}{l}\text { Okoboi } 2016 \\
{[53]}\end{array}$ & Uganda & $\begin{array}{l}\text { Community based } \\
\text { distribution points } \\
\text { (CBDP) }\end{array}$ & $\begin{array}{l}\text { Health care } \\
\text { facility }\end{array}$ & $\begin{array}{l}\text { CDDP } \\
n=476 \\
\text { HCF } n= \\
752\end{array}$ & 5 years & $\begin{array}{l}\text { Overall retention rates were above } 80 \% \text { in both HCF and CBDP } \\
\text { Retention rates }-83.9 \% \text { in the facility and } 82.9 \% \text { retained in } \\
\text { the community distribution model of delivery }(p=0.670)\end{array}$ \\
\hline $\begin{array}{l}\text { Jobarteh } 2016 \\
\text { [54] }\end{array}$ & Mozambique & $\begin{array}{l}\text { Community ART } \\
\text { support groups (CASG) }\end{array}$ & $\begin{array}{l}\text { Health care } \\
\text { facility (non- } \\
\text { CASG) }\end{array}$ & $\begin{array}{l}\text { CAGs } \\
n=6760 \\
\text { HCF } n= \\
123,178\end{array}$ & 12 months & $\begin{array}{l}\text { LTFU - LTFU among CASG and non-CASG members was } 7.2 \\
\text { and 15.9\%, respectively. Compared with CASG participants, } \\
\text { non-CASG participants had significantly higher LTFU (hazard ra- } \\
\text { tio [HR]: 2.36; } 95 \% \text { confidence interval [CI]: } 1.54-3.17 ; p=.04] \\
\text { Mortality -no significant mortality differences between CASG } \\
\text { and non-CASG members (1.4\% vs 1.2\%) (HR:0.98; } 95 \% \mathrm{Cl}, 0.14 \text { to } \\
\text { 1.82; } p=0.96 \text { ) }\end{array}$ \\
\hline $\begin{array}{l}\text { Okoboi } 2015 \\
{[36]}\end{array}$ & Uganda & $\begin{array}{l}\text { Community } \\
\text { distribution points } \\
\text { (CDDP) }\end{array}$ & No comparator & $\begin{array}{l}\text { CDDP } \\
n=3340\end{array}$ & 5 years & $\begin{array}{l}\text { Community-based ART distribution systems are capable of } \\
\text { overcoming barriers to ART retention and result in good rates } \\
\text { of virologic suppression. } \\
\text { Viral suppression- of the } 870 \text { patients who had a VL } \\
\text { measured, } 87 \% \text { were suppressed } \\
\text { Mortality- mortality rate was low ( } 3.22 \text { per } 100 \text { person-years) } \\
\text { LTFU- } 1.59 \text { per } 100 \text { person-years } \\
\text { Retention- more than } 69 \% \text { of patients who initiated ART from } \\
2004 \text { to } 2009 \text { were retained in care after more than } 5 \text { years of } \\
\text { treatment. }\end{array}$ \\
\hline $\begin{array}{l}\text { Decroo } 2014 \\
{[32]}\end{array}$ & Mozambique & $\begin{array}{l}\text { Community ART } \\
\text { groups (CAGs) }\end{array}$ & No comparator & $\begin{array}{l}\text { CAGs } \\
n=6158\end{array}$ & 4 years & $\begin{array}{l}\text { Long-term retention in CAG was exceptionally high [91.8\% at } 4 \\
\text { years of follow-up ( } 95 \% \mathrm{Cl}, 90.1 \text { to } 93.2)] \text {. } \\
\text { LTFU - event rate was } 0.1 \% \text { per 100-person yrs. } \\
\text { Mortality - event rate was } 2.1 \text { per 100-person yrs. } \\
\text { Retention among CAG members at 1 year on ARTwas } 97.7 \% \\
(95 \% \mathrm{Cl} 97.4-98.2) \text {; at } 2 \text { years, } 96.0 \% \text { ( } 95 \% \mathrm{Cl} 95.3-96.6) \text {; at } 3 \\
\text { years, } 93.4 \%(95 \% \mathrm{Cl} 92.3-94.3) \text {; and at } 4 \text { years, } 91.8 \% \text { ( } 95 \% \mathrm{Cl} \\
90.1-93.2) \text {. } \\
\text { Overall, the attrition rate was } 2.2 \text { per } 100 \text { person-years among } \\
\text { the } 5729 \text { adult members. }\end{array}$ \\
\hline Study & Setting & $\begin{array}{l}\text { Non-facility based } \\
\text { model }\end{array}$ & Comparator & $\begin{array}{l}\text { Sample } \\
\text { size }\end{array}$ & $\begin{array}{l}\text { Length of } \\
\text { follow-up }\end{array}$ & Key outcomes \\
\hline $\begin{array}{l}\text { Luque-Fernandez } \\
2013[55]\end{array}$ & South Africa & $\begin{array}{l}\text { Community Adherence } \\
\text { clubs }\end{array}$ & $\begin{array}{l}\text { Health care } \\
\text { facility }\end{array}$ & $\begin{array}{l}\text { ACs } n= \\
502 \\
\text { HCF } n= \\
2372\end{array}$ & 3 years & $\begin{array}{l}\text { Outcomes less frequent in patients participating in the clubs. } \\
\text { Viral rebound }-214 \text { patients had viral failure at study end in } \\
\text { the HCF ( } 90.4 \text { event rates per } 1000 \text { person yrs. [95\%Cl: } 79.1- \\
103.4 \text { ). In the clubs } 14 \text { had viral rebound } 31.8 \text { event rates per } \\
1000 \text { person yrs. } \\
\text { Retention - } 97 \% \text { of club patients remained in care compared } \\
\text { with } 85 \% \text { of other patients. In adjusted analyses club } \\
\text { participation reduced loss-to-care by } 57 \% \text { (hazard ratio [HR] } \\
0.43,95 \% \mathrm{Cl}=0.21-0.91 \text { ). } \\
\text { Mortality }+ \text { LTFU - } 12.8 \% \text { of patients were LTF or had died ( } 323 \\
\text { LTF and } 40 \text { deaths). } \\
\text { Both outcomes were less frequent for patients participating in } \\
\text { the clubs ( } 29.8 \text { vs } 116.8 \text { per } 1000 \text { person-yrs. for LTFU/death, } \\
\text { crude rate ratio [RR }=0.25,95 \% \text { Cl } 0.14-0.41]\end{array}$ \\
\hline Kipp 2012 [56] & Uganda & $\begin{array}{l}\text { Home based ART } \\
\text { delivery }\end{array}$ & $\begin{array}{l}\text { Health care } \\
\text { facility }\end{array}$ & $\begin{array}{l}\operatorname{HBD} n= \\
185 \\
\mathrm{HCF} n= \\
200\end{array}$ & 24 months & $\begin{array}{l}\text { ART outcomes such as viral suppression in community models } \\
\text { were equivalent to those receiving care in the facility. } \\
\text { Viral suppression - patients in the home delivery model were } \\
2.47 \text { times more likely to achieve viral suppression compared to } \\
\text { those in the facility based [95\% CI for OR } 1.02-6.04 p=0.046] \text {. } \\
\text { Mortality - 32(17\%) in Home delivery vs } 23(12 \%) \text { in HCF. This } \\
\text { had limitations as the LTFU in both groups includes unknown } \\
\text { number of deaths. Crude mortality was higher in the HBD } \\
\text { cohort compared to the HCF cohort, though this difference } \\
\text { was not statistically significant (17.3\% vs. } 11.5 \%, p=0.10) \text {. } \\
\text { Retention - } 70 \% \text { in home model vs } 71 \% \text { in facility }\end{array}$ \\
\hline
\end{tabular}

\section{CROSS-SECTIONAL STUDY}

Viral suppression- over the course of the study period, $94 \%$ were virally suppressed

models outside the healthcare facility including facility or adherence clubs, home-based delivery, community adherence groups or distribution points and outreach ART delivery (Table 1). ART delivery was done by a range of community healthcare workers, volunteers and nurses.

The six randomised control trials were appraised using the Cochrane tool for risk of bias. Sequence generation 
and allocation concealment were well conducted, and risk of bias was low amongst the studies. Blinding of participants and personnel was not possible in any of the studies due to the nature of the intervention, but there was variability amongst blinding of outcome assessors as in some cases the assessors were also involved in project management. The data collected however were generally objective measures obtained from medical records, which is at minimal risk of bias, even for assessors who were informed of patient allocation. Not all RCTs had published study protocols, which increases the risk of selective outcome reporting, but all did report numbers of attrition and mortality, minimising risk from incomplete outcome data.

\section{Virological suppression (VS) and viral load (VL)}

From our included studies, 10 out of 21 reported VS or HIV viral load rebound as an outcome measure. Of these, three articles $[36,49,57]$ did not compare to a facility-based cohort and were therefore excluded from the pooled analysis. Three articles [37, 41, 44] were RCTs that compared outcomes to a facility-based cohort, one of which [37] included results from two separate RCTs published in the same article. The remaining four studies were all observational cohort studies [47, 52, 55, 56] comparing VS among participants receiving community-based care with those receiving facilitybased care. The pooled risk difference of virological suppression amongst RCTs are shown in Fig. 2, and including the observational studies are shown in Additional file 4: Appendix 4. There was a remarkably consistent effect $\left(\mathrm{I}^{2}=0.04 \%\right)$ found across the four randomized trials, very marginally in favour of community care, with an overall estimated risk difference of $1 \%$ [95\%CI $-1,4 \%$ ). There was no statistically significant evidence $(p=0.24)$ of a difference in viral suppression between the two groups. The definition of viral suppression varied between studies, with Geldsetzer et al. using < 1000 copies/ $\mathrm{ml}$, Fox at al using $<400$ copies/ml, and Selke not defining it. The viral load or suppression reported at baseline in these RCTs also varied. Geldsetzer reported the percentage of people with $\mathrm{VL}<1000$ copies/ml or $\mathrm{CD} 4<350$ cells/ $\mu \mathrm{l}$ (which was $17.4 \%$ in control and $15.4 \%$ in intervention group),. Fox reported the median viral load (copies/ml) and interquartile range. For the adherence club (AC) control and intervention groups, these were 50 (20-124) for both and in the Decentralized Medication Delivery (DMD) control and intervention groups these were $42(20-100)$ and 124 (35-124) respectively. Selke reported the proportion with detectable viral load at baseline, which was $8.5 \%$ in the intervention and 12.6 in the control group. These were all studies assessed as high quality, and apart from not being blinded, all had an overall low risk of bias. Three of the four observational studies showed results broadly consistent with the randomised trial results (although slightly more favourable towards nHFBC, with risk differences ranging from 4 to 6\%). One study by Grimsrud et al. had results showing much greater viral suppression in nHFBC (estimated risk difference of $39 \%$ ), although in that paper the patients receiving nHFBC were those who were classed as "stable on ART" and the comparison group were not (adjusted results for VS were not presented in the paper) [52].

\section{Mortality}

Nine papers were identified that reported mortality, four of which were RCTs. Only two RCTs [42, 43] did a formal comparison between trial arms on mortality. The two RCTs included in the pooled analysis were rated as fair quality, and reported the results stratified by whether baseline CD4 count was less than or greater than 50, increasing the accuracy of the intervention comparison. The other two RCTs reporting extremely low rates of mortality (Selke et al. reported no deaths in HFBC and one in nHFBC and Geldsetzer et al. reported two in HFBC and one in nHFBC). Of the five observational cohort studies, four reported a formal comparison of mortality. The hazard ratios across all studies ranged

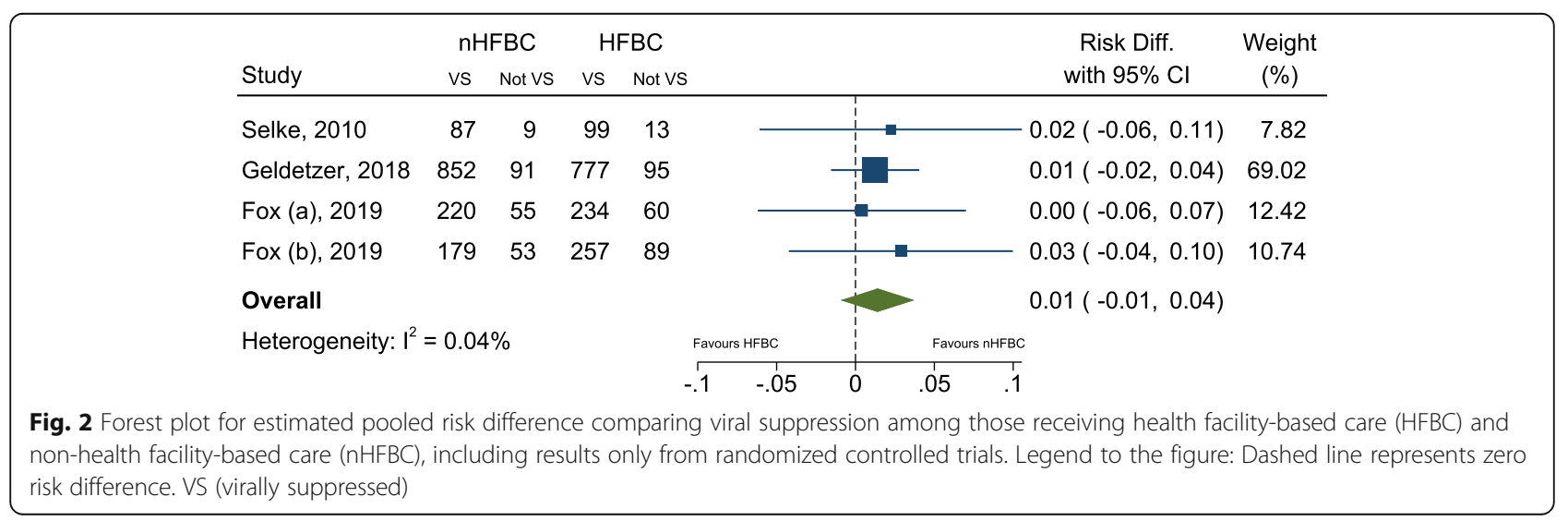




\begin{tabular}{|l|l|l|l}
\hline Study & Hazard ratio \\
Randomised controlled trials & \\
Amuron, 2011 &
\end{tabular}

from 0.8 up to 1.2 , but with all confidence intervals crossing the null of $\mathrm{HR}=1$ (Fig. 3). This resulted in a pooled estimate equal to 1.01 (95\% CI $0.88-1.16$ ), providing no evidence $(p=0.92)$ of a difference in the mortality rate among those not in facility-based care compared to those in facility-based care.

Due to the large amount of heterogeneity, results were described for LTFU and retention in care without formal methods of statistical comparison. Instead, data was tabulated comparing reported outcomes. A page referencing guide for the SWiM guideline for these outcomes can be found in Additional file 5: Appendix 5.

\section{Loss to follow-up}

A total of 15 studies reported LTFU as an outcome, of which four were from RCTs and 11 from observational cohort studies and are summarized in Table 1 and Additional file 6: Appendix 6. In most studies LTFU was defined as no longer having contact with the care services, but there was a large degree of variability in the time frame. This commonly ranged from 60 days to 6 months, however multiple studies defined LTFU as no visit or contact with the service during the study period, which was up to $5 \mathrm{y}$. Additionally, there were varying degrees of investigation into outcomes of the LTFU populations, with some studies documenting mortality and transfer to alternative services, and some not documenting any.

In the studies included, there were four RCTs that included LTFU as an outcome where LTFU was defined as outlined in Additional file 6: Appendix 6 and varied between studies [34, 40, 42, 44]. A cluster RCT undertaken in South Africa comparing adherence clubs with healthcare facility clubs over a 24 months period showed 105 patients were LTFU with no significant difference between the two study arms [40]. Their definition varied from those used in other studies as it was a measure of loss from their intervention, which goes beyond missing visits, but also includes patients who developed any of the exclusion criteria, such as comorbidity or viral rebound. A RCT in Tanzania [41] compared home delivery to HFBC, and defined LTFU as not having a VL measurement after enrolment into the model of care over the entirety of the 12-month study period. They demonstrated noninferiority in the rates of LTFU. In the other two randomised trials by Selke et al. and Woodd et al., LTFU was defined as not having had contact with the care services during the study period, which was 28 months in both studies. Selke et al. [44] compared home delivery model to healthcare facility in Kenya and showed comparable LTFU outcomes (4.5\% in HFBC versus $5.2 \%$ in home delivery) and similarly, Wood et al. compared home delivery to HFBC in Uganda and demonstrated similar rates of LTFU, which were $2.36 \%$ in the facility and $2.33 \%$ in the community [42].

Eleven observational studies reported LTFU with varying definitions. Six of these studies did a comparison between nHFBC and HFBC and showed nHFBC had comparable or better LTFU outcomes compared to HFBC [45, 50-52, 54, 55] (Additional file 6: Appendix 6: Table 4). Among these, LTFU was defined as being late for their scheduled pharmacy pick-up date by either 60 , 90 or 180 days late with the exception of Tun et al. who defined LTFU as combined mortality, transfer out and withdrawal [45]. Grimsrud et al. showed community 
adherence clubs were associated with a reduction in the risk of LTFU compared with the clinic with a two-third reduction in the hazard of LTFU [52] (Additional file 6: Appendix 6). Luque-Fernandez et al. compared adherence clubs to healthcare facility and demonstrated that a combined outcome of time to either death or LTFU was less frequent in club participation than in the facility (crude RR 0.25 95\%CI: 0.14, 0.41) [55]. Similarly, in Mozambique, patients who participated in community adherence support groups were associated with a lower LTFU rates as compared to those who did not participate in these groups. Auld et al. showed participating in CAGs was associated with a $35 \%$ lower LTFU rates (AHR 0.65; 95\%CI: 0.46, 0.91) [51]. Another study comparing CAG to non-CAG showed higher LTFU rates amongst non-CAG members (HR 2.36 95\%ci: 1.54, 3.17) [54]. In the same country, a comparison between CAGs and HFBC showed that CAG members had a greater than 5-fold reduction in the risk of combined LTFU and mortality (adjusted HR 0.18 95\%CI: 0.11, 0.29) [50]. A total of five studies had no comparison to HFBC [32, 36, $46,48,49]$ and despite varying definitions of LTFU, a study in South Africa showed a cumulative incidence of LTFU at 2.6 and $12.2 \%$ at 12 and 24 months respectively [48, 49] (Additional file 6: Appendix 6: Table 5).

The definition of LTFU varied amongst included studies, including a missed scheduled visit, being late for drug pick-ups or withdrawal from a model, which could include death or patients transition to alternative health care facility. For studies that defined LTFU as having missed a scheduled visit or model withdrawal, only three indicated patients transition to $\operatorname{HFBC}[40,41,45]$.

\section{Retention}

A total of 13 studies in our review, two of which were published in the same paper [37], reported retention as an outcome, nine of which provided a comparison to health facility based care (Additional file 6: Appendix 6 Table 4). Three RCTs compared retention between nHFBC and HFBC [37, 41, 44], which showed that the community models had comparable rates to those in the facility. Fox et al. defined retention as those not LTFU, died or transferred to alternative care, and reported $81.6 \%$ participants retained in facility and $89.5 \%$ participants retained in the community with a risk difference of $7.8 \%$ [37]. Selke et al. defined it as those still in care at the end of the follow up period, reporting rates of $91.1 \%$ in facility compared to $90.6 \%$ in the community [44]. Similarly, Geldsetzer et al. defined attrition as those no longer in care, the inverse rates of which are reported as retention of $86.4 \%$ in the facility and $81.1 \%$ in the community [41].

Equally, most observational studies demonstrated similar retention outcomes between nHFBC and HFBC [45,
$53,56]$ or better retention outcomes in nHFBC $[50,54]$. Only one study showed better HFBC retention rates [37]. Definitions of retention in care used were similar across all studies, however there was large variation in follow up period, ranging from six months to five years. Among the four studies that did not provide a comparison to HFBC, retention rates for nHFBC generally exceeded $90 \%$, including a study with follow up of four years. A study from 2015 by Okoboi et al. was the exception, reporting a retention rate of $69 \%$ in patients on treatment for more than five years [36].

\section{Discussion}

We reviewed articles describing the current evidence of community ART programs taking place in SSA between 2010 and 2019 on the following key outcomes; Viral load suppression, mortality, LTFU and retention. From our review, all the articles that described nHFBC ART programs found evidence that decentralizing HIV services into the community for PLHIV has promising outcomes and is a safe alternative to facility based care programs in resource limited high burden HIV settings for stable PLHIV on ART. Adherence clubs that were physically located within the health-care facility were also considered as nHFBC as they ran independently and thus considered as outside the standard HCF provision. The studies suggest that levels of VS and mortality are similar in both nHFBC and HFBC groups. Similarly, with regards to LTFU and retention, articles included in our review showed comparable or slightly better LTFU and retention outcomes amongst nHFBC models when compared to HFBC. However, whilst we identified 21 articles that described one or more outcomes of nHFBC models in SSA countries, only two-thirds of the articles compared these models to the HFBC, limiting the strength of conclusions that can be drawn.

In all included articles, the primary clinical care provider for these nHFBC models was poorly described, but provision of the core packages such as ART dispensation, adherence support and referrals of sick patients to the clinics was often shared by community or trained lay workers. nHFBC models have shown that decentralizing HIV services into the community may potentially overcome major structural and financial barriers faced by PLHIV to ART initiation and retention [27]. These models are capable of achieving a range of potential additional benefits to healthcare providers and PLHIV on ART, including patient satisfaction, reduced costs, convenient and efficient service delivery and better clinical outcomes and promote healthy behaviors such as decrease alcohol abuse [23]. As the numbers of PLHIV accessing treatment increases following the 2015 WHO ART guidelines [9], nHFBC models have shown the potential to be able to deliver a package of essential ART 
services beyond the clinic, freeing up the capacity within the HFBC workforce to be able to focus on more complex cases [24].

Our findings suggest that nHFBC programs can achieve favorable outcomes for stable PLHIV on ART in resource limited settings, which is in line with a previously published systematic review by Decroo et al. that looked at community-based intervention programs [24]. This review has updated and summarized the evidence that has been published since Decroo et al's review in 2013, and proposes that community-based intervention programs can make treatment readily accessible and affordable as well as help support adherence and sustain retention of patients on ART over the long term [24]. In Uganda, Kenya and Tanzania, lay workers or community health workers delivered ART to patients homes [41, 44, 61] whereas in Tete, Mozambique, CAGs were used to deliver ART within the community [50]. Similarly, in South Africa, adherence clubs piloted by MSF equally showed promising results [55].

With respect to other relevant outcomes, studies comparing CD4 count outcomes between HFBC and nHFBC models showed patients in nHFBC models can achieve similar outcomes in terms of CD4 gains [44, 52]. Decroo et al. also included studies analyzing costs of the interventions, and found that provider costs were either similar or lower in nHFBC models, and considerably more cost-effective for patients [24]. Our review did not include cost-analysis as there have been very few studies that have informed on the costs or cost-effectiveness of these nHFBC models. Studies that have reported on costs have found that provider outcomes were similar for HFBC and nHFBC [62, 63]. One study found that community-based intervention programs were much more cost-effective than estimates for facility based care [64]. However, a recent study in Tanzania showed that although patient satisfaction with a home-based program was high and was likely to save patients substantial amount of time, other envisaged benefits of decongesting the healthcare facility and reductions in patients' health expenditures were minimal [41]. Clearly more research using economic outcomes in different contexts to compare the costs, effectiveness and sustainability of the models are needed. Available data suggests that these models, even if equivalent or significantly non-inferior to the HFBC, may be more cost-effective. Patient transportation costs and use of personnel, operational and utility costs are likely to be lower. This in addition to improved retention rates are more likely to make nHFBC models more cost-effective and sustainable in the long run [23].

At the time of writing, Long et al. published a rapid review of differentiated service delivery models for ART in SSA and noted despite the widespread expectations that these models will be cost-saving, they found little data to support this contention [65]. When evaluating programmatic costs of such nHCFB models of ART delivery, an additional cost that is difficult to measure is the potential costs associated with onward HIV transmission amongst those who interrupt ART with consequent viral rebound.

nHFBC models also have the potential to have an impact on the relationship between healthcare providers and patients and can thus strengthen social and peer support [66]. These models have the opportunity to transform the current siloes to a more integrated approach that will enable HIV care to be combined with care for other conditions, including non-communicable diseases that are becoming more prevalent in resource limited settings [23].

Our study had several limitations and despite searching several databases, yielded a small number of studies that looked at ART delivery for final inclusion. We also noted there is paucity of data from other regions in Africa such as West and Central Africa where the HIV burden is high. nHFBC delivery models are recent strategies and at present resource constraints make this a challenge in many sub-Saharan African settings. The heterogeneity of these nHFBC models in our review ranged from the diversity of the models, be definition and the evaluation methods. Of the 21 articles that were included for inclusion only 15 articles compared outcomes with HFBC, making data available for analysis limited, and its inclusion in the meta-analysis imperfect. Instead of comparing outcomes from every individual nHFBC model to HFBC model separately, the results were pooled, and all community-based programs were evaluated against the standard of care causing clinical heterogeneity. Another limitations in this review include the heterogeneity of the articles that met our inclusion criteria which could have manifested in several ways. Our topic was diverse and the methods of evaluating nHFBC outcomes ranged from facility-site, observational cohorts to randomized trials. With regards to studies reporting on mortality in our review, two observational studies did a comparison between patients who chose nHFBC or not $[51,54]$ and one study did a comparison in two different settings [56] which could have resulted in bias due to the fact that whether participants received nHFBC or HFBC was not allocated at random. The reported effect estimates were adjusted for potential confounders to mitigate this. Although some residual confounding may remain, the effect observed in the observational cohorts is consistent with that seen in the randomized studies. Assessing outcomes such as LTFU in our review was also a limitation. The lack of a standard definition for LTFU across studies included in our review made it difficult to assess the trends and differences in LFTU to accurately measure the effectiveness of 
these programs and obstructed comparibility between HFBC and nHFBC models. LTFU is an important indicator to accurately measure effectiveness of ART programs and therefore there is need for a standard definition in order to understand the changes within and the differences between ART programs especially in settings where ascertainment of mortality is weak. Lastly, unsuccessful pilot studies are less likely to be published, introducing publication bias. Studies included in this review introduce bias in measured outcomes in that those included with available data may differ in terms of stability, ability to access care and treatment or being able to make a choice. The value of such nHFBC models for people currently not retained in care is not included in this systematic review. Other limitations include the diversity of the set-up of these nHFBC models and the study design, resulting in observation bias, and confounding bias when a comparison was made. In this review, stable patients were offered the chance or were able to choose themselves and both avenues introduce significant selection bias, as both these groups are likely to contain individuals more dedicated to their health, evident from their superior clinical outcomes or willingness to participate actively in their care.

Although our findings have shown that nHFBC models can complement HFBC service delivery with regards to clinical outcomes and enhance patients ability to manage HIV, there is need for more in depth information on patients acceptability towards these models of care as well as the negative and positive effects related to stigma and ART delivery in the communities [35].

All the articles in our review, with exception of one [42], focused on stable adult PLHIV on ART, which typically included being on ART for more than 6-12 months and either virally suppressed or immunologically stable. However, there is a need to understand the impact of nHFBC models on key populations who are frequently excluded, such as youth and men who have sex with men, who may benefit the most as they may avoid clinics for other reasons such as domestic violence. There is no data regarding nHFBC models towards key populations and further pilot studies on nHFBC models should be targeted towards key populations to determine the feasibility and key clinical outcomes. In additon to the models included in this review, there is a growing trend towards supporting ART distribution from drop-in centres, and therefore a need to assess their effectiveness. However, at the time of evalaution, there were no RCTs that included this approach to explore their outcomes. There is currently scarce or no data regarding patient satisfaction and improvement in quality of life from these models and therefore further research is needed to determine patient satisfaction and quality of life from these models. Feasibility of implementing these models equally need to be explored as most of these models are implemented by in-country implementing partners with additional funding and resources, and need to understand how these models can be placed into the context of existing healthcare sytem without external funding.

\section{Conclusions}

This systematic review further demonstrates noninferiority of nHFBC amongst stable PLWH on ART in high HIV burden, resource limited settings in subSaharan Africa for key outcome measures of VS, death or LTFU compared with current standard HFBC models.

\section{Abbreviations}

AC: Adherence clubs; ART: Antiretroviral treatment; CAG: Community adherence group; CBDP: Community-based distribution group; CHW: Community health worker; DMD: Decentrlaized medication delivery; HFBC: Health facility based care; HIV: Human immunodeficiency virus; LTFU: Loss to follow up; MSF: Médecins Sans Frontiéres; nHFBC: Non-facility based care; PLHIV: People living with HIV; RCT: Randomised control trial; SSA: Sub-Saharan Africa; VL: Viral load; VS: Viral suppression

\section{Supplementary Information}

The online version contains supplementary material available at https://doi. org/10.1186/s12889-021-11053-8.

Additional file 1: Appendix 1. Search strategy in full for all databases, including Medline, Embase and Global Health

Additional file 2: Appendix 2: Table 2. Quality Assessment of Randomised Control Trials using Cochrane Tool for Risk of Bias

Additional file 3: Appendix 3: Table 3. Quality Assessment of Included Cohort Studies using the Newcastle-Ottawa Scale

Additional file 4: Appendix 4: Figure 4. Forest plot for estimated pooled risk difference comparing viral suppression among those receiving health facility based care (HFBC) and non-health facility based care ( $\mathrm{HHFBC}$ ), including results from randomized controlled trials and observational studies. Information on file format. Brief description of file content.

Additional file 5: Appendix 5. Synthesis Without Meta-analysis (SWiM) reporting items

Additional file 6: Appendix 6: Table 4. Loss to Follow-Up and Retention outcomes of nHFBC and HFBC comparison. Table 5. Loss to FollowUp and Retention outcomes without nHFBC and HFBC comparison.

\section{Acknowledgements}

Not Applicable.

\section{Authors' contributions}

Conceptualization, SF and HA; Investigation, ML and GZ; Quantitative analysis, DM; Writing - Original Draft, ML and GZ; Writing - Review and Editing, ML, GZ, DM, SF; Supervision, SF and HA. All authors have read and approved the manuscript.

\section{Funding}

We would like to acknowledge the salary support offered to authors ML and SF by the HPTN 071 (PopArt) study which is sponsored by the National Institute of Allergy and Infectious Disease (NIAID) under Cooperative Agreements UM1-Al068619, UM1-Al068617, and UM1-Al068613, and the Imperial College NIHR BRC respectively. The funders provided no guidance with regards to study design, data collection or analysis. 


\section{Availability of data and materials}

The datasets used and/or analysed during the current study available from the corresponding author on reasonable request.

\section{Declarations}

\section{Consent for publications}

Not Applicable.

\section{Ethics approval and consent to participate}

Not applicable.

\section{Competing interests}

The authors have no competing interests to declare.

\section{Author details}

'Zambart House, PO Box 50697, UNZA-Ridgeway Campus, Lusaka, Zambia. ${ }^{2}$ Imperial College London, London, UK. ${ }^{3}$ MRC Tropical Epidemiology Group, London School of Hygiene and Tropical Medicine, London, UK. ${ }^{4}$ Imperial College and Imperial college NIHR BRC, London, UK.

\section{Received: 4 July 2020 Accepted: 12 May 2021}

\section{Published online: 10 June 2021}

\section{References}

1. UNAIDS. Global HIV \& AIDS statistics - 2020 fact sheet. [cited 2020Jan12]. Available from: https://www.unaids.org/en/resources/fact-sheet.

2. UNAIDS. Fact sheet - Latest statistics on the status of the AIDS epidemic 2018.[Available from: https://www.unaids.org/en/regionscountries/countries/ zambia. Accessed 4 Jan 2019.

3. INSIGHT START Study Group. Initiation of antiretroviral therapy in early asymptomatic HIV infection. N Engl J Med. 2015;373(9):795-807. https://doi. org/10.1056/NEJMoa1506816.

4. Group TTAS. A trial of early Antiretrovirals and isoniazid preventive therapy in Africa. N Engl J Med. 2015:373(9):808-22

5. Cohen MS, Chen YQ, McCauley M, Gamble T, Hosseinipour MC, Kumarasamy N, et al. Antiretroviral therapy for the prevention of HIV-1 transmission. N Engl J Med. 2016;375(9):830-9. https://doi.org/10.1056/ NEJMoa1600693.

6. Rodger AJ, Cambiano V, Bruun T, et al. PARTNER Study Group. Sexual activity without condoms and risk of HIV transmission in serodifferent couples when the HIV-positive partner is using suppressive antiretroviral therapy. JAMA. 2016;316(2):171-81. https://doi.org/10.1001/jama.2016.5148.

7. Eisinger RW, Dieffenbach CW, Fauci AS. HIV viral load and transmissibility of HIV infection: undetectable equals Untransmittable. JAMA. 2019;321(5):4512. https://doi.org/10.1001/jama.2018.21167.

8. UNAIDS. UNAIDS fast-track: ending the AIDS epidemic by 2030. Geneva; 2014

9. WHO. Guidelines on when to start antiretroviral therapy and on preexposure prophylaxis for HIV. Geneva. 2015.

10. Tymejczyk O, Brazier E, Yiannoutsos CT, Vinikoor M, van Lettow M, Nalugoda $F$, et al. Changes in rapid HIV treatment initiation after national "treat all" policy adoption in 6 sub-Saharan African countries: regression discontinuity analysis. PLOS Med. 2019;16(6):e1002822. https://doi.org/10.1371/journal. pmed.1002822.

11. World Health Organization. WHO HIV policy adoption and implementation status in countries: fact sheet. Geneva: World Health Organization; 2018.

12. UNAIDS. UNAIDS data 2019.

13. UNAIDS. Global AIDS update 2018: miles to go. Geneva: Joint united Nations Preogramme on HIV/AIDS (unaids); 2018.

14. Sanjana P, Torpey K, Schwarzwalder A, Simumba C, Kasonde P, Nyirenda L et al. Task-shifting HIV counselling and testing services in Zambia: the role of lay counsellors. Hum Resour Health. 2009;7(1):44. https://doi.org/10.11 86/1478-4491-7-44

15. Hirschhorn LR, Oguda L, Fullem A, Dreesch N, Wilson P. Estimating health workforce needs for antiretroviral therapy in resource-limited settings. Hum Resour Health. 2006;4(1):1. https://doi.org/10.1186/1478-4491-4-1.

16. Fox MP, Rosen S. Patient retention in antiretroviral therapy programs up to three years on treatment in sub-Saharan Africa, 2007-2009: systematic review. Tropical Med Int Health. 2010;15(s1):1-15. https://doi.org/10.1111/ j.1365-3156.2010.02508.x
17. Fox MP, Rosen S. Retention of Adult Patients on Antiretroviral Therapy in Low- and Middle-Income Countries: Systematic Review and Meta-analysis 2008-2013. JAIDS. 2015;69(1):98-108.

18. Rosen S, Fox MP. Retention in HIV care between testing and treatment in sub-Saharan Africa: a systematic review. PLoS Med. 2011;8(7):e1001056. https://doi.org/10.1371/journal.pmed.1001056.

19. Mugglin C, Estill J, Wandeler G, Bender N, Egger M, Gsponer T, et al. Loss to programme between HIV diagnosis and initiation of antiretroviral therapy in sub-Saharan Africa: systematic review and metaanalysis. Trop Med Int Health. 2012;17(12):1509-20. https://doi.org/1 0.1111/j.1365-3156.2012.03089.x.

20. Kranzer K, Govindasamy D, Ford N, Johnston V, Lawn SD. Quantifying and addressing losses along the continuum of care for people living with HIV infection in sub-Saharan Africa: a systematic review. J Int AIDS Soc. 2012; 15(2):17383. https://doi.org/10.7448/IAS.15.2.17383.

21. Fox MP, Shearer K, Maskew M, Meyer-Rath G, Clouse K, Sanne I. Attrition through multiple stages of pre-treatment and ART HIV Care in South Africa. PLoS One. 2014;9(10):e110252. https://doi.org/10.1371/journal.pone.0110252.

22. Joint United Nations Programme on HIV/AIDS. 90-90-90:an ambitious treatment target to help end the AIDS epidemic. Geneva: UNAIDS; 2014.

23. Nachega JB, Adetokunboh O, Uthman OA, Knowlton AW, Altice FL Schechter $M$, et al. Community-based interventions to improve and sustain antiretroviral therapy adherence, retention in HIV care and clinical outcomes in low- and middle-income countries for achieving the UNAIDS 90-90-90 targets. Curr HIV/AIDS Rep. 2016;13(5):241-55. https://doi.org/10.1007/s11 904-016-0325-9.

24. Decroo T, Rasschaert F, Telfer B, Remartinez D, Laga M, Ford N. Communitybased antiretroviral therapy programs can overcome barriers to retention of patients and decongest health services in sub-Saharan Africa: a systematic review. Int Health. 2013:5(3):169-79. https://doi.org/10.1093/inthealth/iht016.

25. ICAP Approach to Differentiated Service Delivery [Internet]. Cquin.icap. columbia.edu. 2019 [cited 16 Sep 2019]. Available from: https://cquin.icap. columbia.edu/resources/icap-approach-to-differentiated-service-delivery/ [.

26. International AIDS Society (IAS). DIFFERENTIATED CARE FOR HIV: A Decision Framework for Antiretroviral Therapy Delivery: International AIDS Society; 2016

27. Bemelmans M, Baert S, Goemaere E, Wilkinson L, Vandendyck M, Cutsem G, et al. Community-supported models of care for people on HIV treatment in sub-Saharan Africa. Tropical Med Int Health. 2014;19(8):968-77. https://doi. org/10.1111/tmi.12332.

28. Wilkinson LS. ART adherence clubs: A long-term retention strategy for clinically stable patients receiving antiretroviral therapy. 2013. 2013;14(2):3.

29. Grimsrud A, Sharp J, Kalombo C, Bekker L-G, Myer L. Implementation of community-based adherence clubs for stable antiretroviral therapy patients in Cape Town, South Africa. 2015.

30. Grimsrud A, Bygrave H, Doherty M, Ehrenkranz P, Ellman T, Ferris $R$, et al Reimagining HIV service delivery: the role of differentiated care from prevention to suppression. J Int AIDS Soc. 2016;19(1):21484. https://doi.org/1 0.7448/IAS.19.1.21484

31. Bochner AF, Meacham E, Mhungu N, Manyanga P, Petracca F, Muserere $C$, et al. The rollout of community ART refill groups in Zimbabwe: a qualitative evaluation. J Int AIDS Soc. 2019;22(8):e25393. https://doi.org/1 0.1002/jia2.25393.

32. Decroo T, Koole O, Remartinez D, dos Santos N, Dezembro S, Jofrisse M, et al. Four-year retention and risk factors for attrition among members of community ART groups in Tete, Mozambique. Trop Med Int Health. 2014; 19(5):514-21. https://doi.org/10.1111/tmi.12278.

33. Community-Based Anti Retroviral Therapy Delivery - Experiences Of Médecins Sans Frontières. (2015). [online] Geneva: Joint United Nations Programme on HIV/AIDS (UNAIDS). Available at: http://www.differentiatedca re.org/Portals/0/adam/Content/smn7ayyQgkeloTiU1t39YA/File/20150420_ MSF_UNAIDS_JC2707-1.pdf [Accessed 24 Jan. 2018].

34. Geldsetzer P, Francis JM, Ulenga N, Sando D, Lema IA, Mboggo E, et al. The impact of community health worker-led home delivery of antiretroviral therapy on virological suppression: a non-inferiority cluster-randomized health systems trial in Dar Es Salaam, Tanzania. BMC Health Serv Res. 2017; 17(1):160. https://doi.org/10.1186/s12913-017-2032-7.

35. Davis N, Kanagat N, Sharer M, Eagan S, Pearson J, Amanyeiwe UU. Review of differentiated approaches to antiretroviral therapy distribution. AIDS Care. 2018:30(8):1010-6. https://doi.org/10.1080/09540121.2018.1441970. 
36. Okoboi S, Ding E, Persuad S, Wangisi J, Birungi J, Shurgold S, et al. Community-based ART distribution system can effectively facilitate longterm program retention and low-rates of death and virologic failure in rural Uganda. AIDS Res Ther. 2015;12(1):1-9.

37. Fox MP, Pascoe S, Huber AN, Murphy J, Phokojoe M, Gorgens M, et al. Adherence clubs and decentralized medication delivery to support patient retention and sustained viral suppression in care: results from a clusterrandomized evaluation of differentiated ART delivery models in South Africa. PLoS Med. 2019;16(7):e1002874. https://doi.org/10.1371/journal. pmed.1002874.

38. Chi BH, Yiannoutsos CT, Westfall AO, Newman JE, Zhou J, Cesar C, et al. Universal definition of loss to follow-up in HIV treatment programs: a statistical analysis of 111 facilities in Africa, Asia, and Latin America. PLoS Med. 2011:8(10):e1001111. https://doi.org/10.1371/journal.pmed.1001111.

39. Covidence. Cochrane Community. https://community.cochrane.org/help/ tools-and-software/covidence. Accessed June 2018.

40. Hanrahan CF, Schwartz SR, Mudavanhu M, West NS, Mutunga L, Keyser V, et al. The impact of community- versus clinic-based adherence clubs on loss from care and viral suppression for antiretroviral therapy patients: findings from a pragmatic randomized controlled trial in South Africa. PLoS Med. 2019;16(5):e1002808. https://doi.org/10.1371/journal.pmed.1002808.

41. Geldsetzer P, Francis JM, Sando D, Asmus G, Lema IA, Mboggo E, et al. Community delivery of antiretroviral drugs: a non-inferiority clusterrandomized pragmatic trial in Dar Es Salaam, Tanzania. PLoS Med. 2018; 15(9):e1002659. https://doi.org/10.1371/journal.pmed.1002659.

42. Woodd S, Grosskurth H, Levin J, Amuron B, Namara G, Birunghi J, et al. Home-based versus clinic-based care for patients starting antiretroviral therapy with low CD4+ cell counts: findings from a cluster-randomized trial. AIDS. 2014;28(4):569-76.

43. Amuron B, Levin J, Birunghi J, Namara G, Coutinho A, Grosskurth H, et al. Mortality in an antiretroviral therapy programme in Jinja, south-East Uganda: a prospective cohort study. AIDS Res Ther. 2011;8(1):39. https://doi. org/10.1186/1742-6405-8-39.

44. Selke HM, Kimaiyo S, Sidle JE, Vedanthan R, Tierney WM, Shen C, et al. Taskshifting of antiretroviral delivery from health care workers to persons living with HIV/AIDS: clinical outcomes of a community-based program in Kenya. J Acquir Immune Def Synd (1999). 2010;55(4):483-90.

45. Tun W, Apicella L, Casalini C, Bikaru D, Mbita G, Jeremiah K, et al. Community-based antiretroviral therapy (ART) delivery for female sex Workers in Tanzania: 6-month ART initiation and adherence. AIDS Behav. 2019;23(2):142-52. https://doi.org/10.1007/s10461-019-02549-X.

46. Pasipamire L, Nesbitt RC, Ndlovu S, Sibanda G, Mamba S, Lukhele N, et al. Retention on ART and predictors of disengagement from care in several alternative community-centred ART refill models in rural Swaziland. J Int AIDS Soc. 2018:21(9):e25183.

47. Myer L, Iyun V, Zerbe A, Phillips TK, Brittain K, Mukonda E, et al. Differentiated models of care for postpartum women on antiretroviral therapy in Cape Town, South Africa: a cohort study. J Int AIDS Soc. 2017; 20(Suppl 4):21636.

48. Vogt F, Kalenga L, Lukela J, Salumu F, Diallo I, Nico E, et al. Brief Report: Decentralizing ART Supply for Stable HIV Patients to Community-Based Distribution Centers: Program Outcomes From an Urban Context in Kinshasa, DRC. J Acquire Immune Def Synd (1999). 2017;74(3):326-31.

49. Tsondai PR, Wilkinson LS, Grimsrud A, Mdlalo PT, Ullauri A, Boulle A. High rates of retention and viral suppression in the scale-up of antiretroviral therapy adherence clubs in Cape Town, South Africa. J Int AIDS Soc. 2017; 20(Suppl 4):21649. https://doi.org/10.7448/IAS.20.5.21649.

50. Decroo T, Telfer B, Dores CD, White RA, Santos ND, Mkwamba A, et al. Effect of community ART groups on retention-in-care among patients on ART in Tete Province, Mozambique: a cohort study. BMJ Open. 2017;7(8):e016800. https://doi.org/10.1136/bmjopen-2017-016800

51. Auld AF, Shiraishi RW, Couto A, Mbofana F, Colborn K, Alfredo C, et al. A Decade of Antiretroviral Therapy Scale-up in Mozambique: Evaluation of Outcome Trends and New Models of Service Delivery Among More Than 300,000 Patients Enrolled During 2004-2013. J Acquir Immune Defic Syndr (1999). 2016;73(2):e11-22.

52. Grimsrud A, Lesosky M, Kalombo C, Bekker LG, Myer L. Implementation and Operational Research: Community-Based Adherence Clubs for the Management of Stable Antiretroviral Therapy Patients in Cape Town, South Africa: A Cohort Study. J Acquir Immune Defic Syndr (1999). 2016;71(1):e16-23.
53. Okoboi S, Ssali L, Yansaneh Al, Bakanda C, Birungi J, Nantume S, et al. Factors associated with long-term antiretroviral therapy attrition among adolescents in rural Uganda: a retrospective study. J Int AIDS Soc. 2016;19(5 Suppl 4):20841. https://doi.org/10.7448/IAS.19.5.20841.

54. Jobarteh K, Shiraishi RW, Malimane I, Samo Gudo P, Decroo T, Auld AF, et al. Community ART support groups in Mozambique: the potential of patients as Partners in Care. PLoS One. 2016;11(12):e0166444. https://doi.org/10.1371/ journal.pone.0166444.

55. Luque-Fernandez MA, Van Cutsem G, Goemaere E, Hilderbrand K, Schomaker M, Mantangana N, et al. Effectiveness of patient adherence groups as a model of care for stable patients on antiretroviral therapy in Khayelitsha, Cape Town, South Africa. PloS One. 2013;8(2):e56088. https:// doi.org/10.1371/journal.pone.0056088.

56. Kipp W, Konde-Lule J, Saunders LD, Alibhai A, Houston S, Rubaale T, et al. Antiretroviral treatment for HIV in rural Uganda: two-year treatment outcomes of a prospective health Centre/community-based and hospitalbased cohort. PLoS One. 2012;7(7):e40902. https://doi.org/10.1371/journal. pone.0040902

57. Chimukangara B, Manasa J, Mitchell R, Nyabadza G, Katzenstein D, Masimirembwa C. Community based antiretroviral treatment in rural Zimbabwe. AIDS Res Hum Retrovir. 2017;33(12):1185-91. https://doi.org/10.1 089/aid.2017.0029.

58. Wells $G$, Shea B, O'Connell D, Peterson J, Welch V, Losos M, Tugwell P: The Newcastle-Ottawa Scale (NOS) for assessing the quality of nonrandomised studies in meta-analyses. 2013. http://www.ohri.ca/programs/clinical_ epidemiology/oxford.asp.

59. Higgins JPT, Thomas J, Chandler J, Cumpston M, Li T, Page MJ, Welch VA (editors). Cochrane Handbook for Systematic Reviews of Interventions version 6.0 (updated July 2019). Cochrane, 2019. Available from www.tra ining.cochrane.org/handbook.

60. Campbell MMJ, Sowden A, Katikireddi SV, Brennan SE, Ellis S, et al. Synthesis without meta-analysis (SWiM) in systematic reviews: reporting guideline. BMJ. 2020:368.

61. Wools-Kaloustian K, Sidle J, Selke H, Vedanthan R, Kemboi E, Boit L, et al. A model for extending antiretroviral care beyond the rural health Centre. J Int AIDS Soc. 2009;12(1):22. https://doi.org/10.1186/1758-2652-12-22.

62. Jaffar S, Amuron B, Foster S, Birungi J, Levin J, Namara G, et al. Rates of virological failure in patients treated in a home-based versus a facility-based HIV-care model in Jinja, southeast Uganda: a cluster-randomised equivalence trial. Lancet (London, England). 2010:374.

63. Kipp W, Konde-Lule J, Rubaale T, Okech-Ojony J, Alibhai A, Saunders D. Comparing antiretroviral treatment outcomes between a prospective community-based and hospital-based cohort of HIV patients in rural Uganda. BMC Int Health Hum Rights. 2011;11(Suppl 2):S12. https://doi.org/1 0.1186/1472-698X-11-S2-S12.

64. Marseille E, Kahn JG, Pitter C, Bunnell R, Epalatai W, Jawe E, et al. The cost effectiveness of home-based provision of antiretroviral therapy in rural Uganda. Appl Health Econ Health Policy. 2009;7(4):229-43. https://doi.org/1 $0.1007 / B F 03256157$

65. Long L, Kuchukhidze S, Pascoe S, Nichols B, Cele R, Govathson C, et al. Differentiated service delivery models for antiretroviral treatment of HIV in sub-Saharan Africa: a rapid systematic review. AMBIT Project Report Number 04. Boston: Boston University and HE2RO; 2020.

66. Decroo T, Van Damme W, Kegels G, Remartinez D, Rasschaert F. Are expert patients an untapped resource for ART provision in sub-Saharan Africa? AIDS Res Treat. 2012:749718.

\section{Publisher's Note}

Springer Nature remains neutral with regard to jurisdictional claims in published maps and institutional affiliations. 